\title{
She-Ra and the Princesses of Power as Queer Monomyth
}

\author{
By Paul Thomas* \\ ORCID: $\underline{0000-0002-5596-7951}$
}

Scheduled to be published as: Thomas, Paul. "She-Ra and the Princesses of Power as Queer Monomyth." Journal of Popular Culture, vol. 54, no. 5, 2021.

\begin{abstract}
In this essay, the author considers the animated television program She-Ra and the Princesses of Power (2018-20) and argues two main things: First, that the She-Ra reboot can be read as monomythic, and second, that it employs the monomyth while also queering normative understandings of heroic gender and sexuality. The end result is a critical remix that stars a hero-Adora - who can be understood as both queer and monomythic. She-Ra and the Princesses of Power thus stands out from the rest of the pack, serving as a shining example for writers wanting to "rehabilitate" Campbell's monomyth in our increasingly queer, feminist, and intersectional world.
\end{abstract}

\section{Keywords}

Gender theory, LGBT, Myth, Popular culture, animation

\footnotetext{
* Paul Thomas is a library specialist at the University of Kansas (paulthomas@ku.edu) as well as a student in the Doctor of Philosophy (Ph.D.) degree program in the School of Library and Information Management, Emporia State University (pthomas@g.emporia.edu).
} 
In 1949, the comparative mythologist Joseph Campbell published The Hero with a Thousand Faces, in which he argued that "the standard path of the ... adventure of the hero is a magnification of the formula represented in the rites of passage: separation-initiation-return: which might be named the nuclear unit of the monomyth" (J. Campbell, Hero 23). While comparative mythology has long since moved past the sort of universalism espoused found in the pages of The Hero with a Thousand Faces, the concept of the "monomyth" has nevertheless remained culturally relevant as a storytelling model, serving as the backbone for numerous books, television series, and films. But despite its popularity as a writing tool, the monomyth has also engendered increasing criticism, especially from queer and feminist writers, who argue that its repeated use often reproduces the heteronormative understandings of heroic gender and sexuality that are to be found in Campbell's original work.

It is at this point that She-Ra and the Princesses of Power (a reboot of the 1980s cartoon She-Ra: Princess of Power produced by DreamWorks) enters into the conversation. Developed by Noelle Stevenson, this masterful remake follows a young woman named Adora, who discovers a mystical sword that provides her with the powers of the titular entity. Adora then sets out to defend her home planet Etheria from the evil Horde, all the while learning what it means to be a true hero. As this brief synopsis perhaps makes obvious, the series is predicated on the main character undertaking a journey of heroic self-discovery and can easily be understood as monomythic; this in and of itself is not remarkable, given the ubiquity of the monomyth in popular culture. What is striking, however, is the way that She-Ra employs the monomyth while also queering normative understandings of heroic gender and sexuality. The end result is a critical remix that stars a hero-Adora-who can be understood as both queer and monomythic. She-Ra and the Princesses of Power thus stands out from the rest of the monomythic pack and serves as a model for writers interested in "rehabilitating" Campbell's monomyth in our increasingly queer, feminist, and intersectional world.

\section{Introduction to She-Ra and Adora}

She-Ra and the Princesses of Power is the 2018 reboot of the animated series She-Ra: Princess of Power (1985-86), which in turn was a spin-off of the quintessential 80s cartoon $\mathrm{He}$ Man and the Masters of the Universe (1983-85). The reboot is set on the planet of Etheria and follows the exploits of Adora (voiced by Aimee Carrero), a young woman who has long served as a soldier of the Horde - an evil, colonizing force led by Lord Hordak (voiced by Keston John).

Adora is a promising cadet who believes she is fighting for the Greater Good, but her future in the Horde is dashed when she gains possession of the Sword of Protection, turning her into the magical guardian of Etheria, She-Ra. After learning the truth about the Horde, Adora joins the Rebellion, where she befriends Bow (a gregarious archer, voiced by Marcus Scribner) and Princess Glimmer (the princess of Bright Moon, voiced by Karen Fukuhara). Most of the series follows Adora and her new friends (a group that Bow dubs the "Best Friend Squad") as they fight against the Horde, which is often led into battle by Catra (voiced by AJ Michalka), a tricky adversary who had previously been Adora's best friend when she was with the Horde.

From the very beginning, it is clear that Adora is the protagonist of the show, but can it be said that she fulfills the requirements of a Campbellian hero, as detailed in Hero with a Thousand Faces? In his book The Monomyth in American Science Fiction Films, Donald E. Palumbo glosses Campbell's work, writing: 
The [monomythic] hero may have been exiled or orphaned, may be seeking his father, and may triumph over pretenders as the true son ([274-286]). His mother may be assumed into heaven or crowned a queen ([99-100]). He possesses exceptional gifts, and the world he inhabits may suffer symbolic deficiencies ([29-30]). He does not fear death, and he may be destined to make the world spiritually significant or humankind comprehensible to itself ([306, 334]). If a warrior, he will change the status quo ([287292]). If a lover, his triumph may be symbolized by a woman and accomplishing the impossible task may lead him to the bridal bed ([293-295]). If a tyrant or ruler, his search for the father will lead to the invisible unknown from which he will return as a lawgiver ([296-298]). If a world-redeemer, he will learn that he and the father are one ([299-303]). If a saint or mystic, he will transcend life and myth to enter an inexpressible realm beyond form ([304-305]). (Palumbo 3-4) ${ }^{1}$

Now, consider these attributes in relation to Adora. First, Adora is a sort of orphan, as she is from the planet Eternia (home of the legendary "First Ones") who was kidnapped and adopted by the Horde when she was a baby (cf. J. Campbell, Hero 275-290); however, She-Ra subverts many of the clichés associated with the "orphaned chosen one" trope by having Adora specifically not seek out her origins or her biological family (Adora, it seems, is perfectly contented with her found family from Etheria). Second, Adora is at the start of the series a talented young woman, whose abilities are exponentially increased when she is filled with the overwhelming powers of the She-Ra (cf. 29-30). Adora also has no fear of death (cf. 306), spending most of the series putting herself directly in harm's way to save her friends and undo the "deficiencies" inflicted upon the planet by the Horde (cf. 29-30). Finally, the character has great spiritual significance for the inhabitants of Etheria, as, once again, she is the manifestation of She-Ra - a quasi-religious entity who can help Etheria "know itself" by rejuvenating the fullness of its magic (cf. 334).

In terms of the conditional categories into which a hero can be sorted, Adora is: an active warrior who rids her world of the Horde via revolution (cf. J. Campbell, 287-292; "Hero as Warrior"), a lover whose romantic feelings for Catra make feasible "the impossible task" of defeating Horde Prime (cf. 293-295; "Hero as Lover"), the titular princess of power (cf. 296-298; "Hero as Ruler"), and the redeemer of Etheria (cf. 299-303; "Hero as World Redeemer"). Finally, while Adora embraces rather than renounces the physical world, as a manifestation of the She-Ra, she does have access to the "inexpressible realm" (Palumbo 4) that is the soul of Etheria itself, making her in many ways a mystical figure (cf. J. Campbell 304-305; "Hero as Saint").

\section{The Monomythic Structure of She-Ra}

Before one can argue that She-Ra queers normative understandings of the monomyth, it is first necessary to establish that the show actually follows the monomyth. According to Campbell, the basic structure of the monomyth is as follows: "A hero ventures forth from the world of common day into a region of supernatural wonder: fabulous forces are there encountered and a decisive victory is won: the hero comes back from this mysterious adventure with the power to bestow boons on his fellow man" (J. Campbell, Hero 23). The ultimate goal of this journey, according to Palumbo, is "enlightenment," which despite its mystical associations means nothing

\footnotetext{
${ }^{1}$ Palumbo's work cites the 1968 version of Hero with a Thousand Faces. For consistency sake, Palumbo's citations have been updated to reflect the 2008 edition of the work, which is used throughout the rest of this essay.
} 
more than the Hero coming to understand the totality of her being (6-7); it is thus a journey of self-realization. As it so happens, She-Ra details Adora's journey of self-realization, which is predicated on her recognition of both her heroic nature (corresponding to her conscious mind) and her repressed love for Catra (corresponding to her unconscious mind).

\section{"On the edge of greatness": The Departure}

According to Joseph Campbell, the monomyth commences when "a blunder-apparently the merest chance - reveals an unsuspected world [to the protagonist], and the individual is drawn into a relationship with forces that are not rightly understood" (Hero 42). Adora's blunder occurs in the series' premiere, "The Sword," when she falls off a skiff while she and her best friend Catra are joyriding through the Whispering Woods. Her fall having knocked her unconscious, Adora experiences a vision of a sword embedded in the earth, and when she touches its hilt, she hears a mysterious voice say: "Balance must be restored, Etheria must seek a hero" ("The Sword"). The world-spirit of Etheria has thus called Adora to adventure, choosing her as the next She-Ra. But before she can comprehend what is happening, Adora's reverie is interrupted by Catra, who hurriedly takes her back to the Fright Zone, the capital of the Horde.

Campbell argues that when first faced with Destiny, the hero is wont to refuse the call (Hero 49-56), choosing to initially remain in the familiar world. In $S h e-R a$, however, this refusal is displaced: After her vision, Adora wants more than anything to return to the forest and find the mysterious sword, but Catra tells her to forget what she saw. Adora's curiosity finally gets the better of her, and one night, she sneaks back into the Whisper Woods and locates the mysterious weapon (which we soon learn is called the Sword of Protection). But as fate would have it, two members of the Rebellion, Princess Glimmer and Bow, are in the area at the same time. They spy Adora seizing the sword and use her preoccupation as an opportunity to ambush her and take her prisoner. Adora and her comrades-at-arms have long been taught that all members of the Rebellion are evil, so she understandably assumes the worst of her captors. But a series of events eventually lead her to recognize that it is actually the Horde that is evil. This revelation is cemented when Glimmer, Bow, and Adora wander into the quaint, peaceful town of Thaymor, only for it to come under attack by a contingent of Horde soldiers, including Catra.

Adora confronts Catra, telling her the truth about Horde, but she is shocked when Catra reveals that she has long known the Horde was up to know good. What is more, Catra insists that she does not care; she is only concerned with herself and Adora. Adora is horrified, given that she has always striven to do the "right" thing, and so she repudiates the Horde - and by extension, Catra herself. Adora then manages to activate the Sword of Protection, turning her into She-Ra and allowing her to route the Horde's forces with ease. Adora has officially answered the call to adventure.

Campbell writes that a hero, having set out on the road of adventure, soon receives supernatural aid by encountering a "protective figure" (often a little old crone or old man)" who represents the "benign, protecting power of destiny" (57, 59). For Adora, there happen to be three such mentors in her journey: The first is Madame Razz, a mysterious "old crone" who lives in the Whispering Woods and who was once close friends with the previous She-Ra, Mara. Razz provides sage wisdom, telling Adora that in moments of doubt, she must "stop waiting for someone to tell [her] what the right thing to do is" ("Razz"). This instills in Adora a sense of existential purpose, encouraging her to pledge her loyalties to Glimmer's mother and leader of the Rebellion, Queen Angella. Angella herself is the second protective figure, who bestows upon Adora a metaphorical gift in the title "Princess of Power," which provides her the courage to 
confront "the dragon forces" (J. Campbell, Hero 57) of the Horde. Adora's final mentor is Light Hope, an artificial intelligence programmed by the First Ones who "lives" in a First One's ruin known as the Crystal Castle and begins to train Adora in the ways of the She-Ra.

Adora pledging her allegiance to the Rebellion is the moment in which she officially crosses the threshold of adventure, entering into a world of "darkness, the unknown, and danger" (J. Campbell, Hero 64). Adora has thus reached the final incident in the Departure stage: the "Belly of the Whale," in which "the hero ... is swallowed into the unknown, and would appear to have died" (74); consequently, when the hero re-emerges from this darkness, it can be said that they have been reborn. Adora experiences this symbolic death and rebirth in the first-season episode "Promise," in which Adora and Catra find themselves trapped in the Crystal Castle (Frankel, Turning Darkness to Light 41). The disappearance of the hero into a space like the Castle "corresponds to the passing of a worshiper into a temple where [she] is to be quickened by the recollection of who and what [she] is" (J. Campbell, Hero 77). For Adora and Catra, this "recollection" takes the form of holographic visions that function as flashbacks, showing them key moments from their childhood. The visions strengthen Adora's resolve to be a hero, but they lead Catra to fully reject Adora. When the two emerge from the castle, they have metamorphosized into archnemeses.

\section{"Turning darkness to light": The Initiation}

The Hero, having successfully crossed the threshold of adventure and entered fully into the special world of adventure, then set out on the "road of trials," during which she is forced to overcome obstacles or outsmart villains. As it stands, the vast majority of She-Ra episodes can be sorted into this stage, as almost all of them focus on Adora and her allies fighting back Horde soldiers, often under the command of Catra.

From a psychological standpoint, this "gauntlet" of tribulations symbolizes the Hero's descent into her unconscious mind, with the phantasmic enemies representing repressed aspects of the Hero's self (J. Campbell, Pathways 114-116). And of all the evil minions and strange beasties lurking in the dark of the unconscious, the enemy that the Hero most commonly encounters at this point in a story is the Shadow. In the analytical psychology tradition of C. G. Jung, the "Shadow" is one of the many "archetypes," representing the contents of the personal unconscious. Campbell argues that in monomythic stories, the Shadow thus functions as the dramaturgical inverse of the hero, personifying all those qualities that the Hero has rejected (Pathways 73-74, 115). If Adora is the Hero of the story, then who is the Shadow? The answer, of course, is Catra, as she is literally Adora's archnemesis, as established in the episode "Promise." But now we face a greater question: Why is Catra Adora's Shadow?

On a surface level, one might say that it is because Catra embodies many traits that are not becoming of a traditional hero, like unpredictability, mercuriality, and a penchant for rulebending, but this answer lacks depth. Instead, the real answer to this quandary (which is only confirmed in the series finale) is much more visceral: Adora romantically loves Catra, and she longs to be with her. Unfortunately, over the course of She-Ra, the audience learns that Adora has developed something of a heroic martyr complex, believing that her destiny as She-Ra precludes any chance that she can live for herself and be happy. Because Adora sees in Catra the real possibility of romantic love, she also sees in Catra the real possibility of true happiness. In Adora's eyes, Catra is thus a temptress - "a succubus leading [her] astray from [her] true path" (J. Campbell, Pathways 117) — and so she pushes Catra away in the misguided name of heroics. 
The problem here is that the Hero and her Shadow exist in a reciprocal relationship, meaning that when the hero "tries desperately to be good and wonderful and perfect," the Shadow will grow "black and evil and destructive" (Jung 35); this explains why the harder Adora tries to be the selfless hero of Etheria, the more malevolent Catra seems to grow. And because the Shadow represents a real aspect of the Hero's psyche, the Shadow cannot simply be beaten into submission. Instead, the only way for the Hero to overcome the challenge of the Shadow is through coniunctio oppositorum (literally, the "union of opposites"), wherein "the shadow ... is raised to consciousness and integrated" with the Hero's understanding of herself (Casement 102). For Adora, this would mean reconciling her calling as a hero (her conscious mind) with her repressed love for Catra (her unconscious mind). Alas, Adora and Catra fail at this unification time and time again, and this emotional drama consequently propels much of the action in the series. (In fact, so drawn-out is the drama that it is not until the Return leg of Adora's journey that her and Catra finally make peace.)

Near the nadir of the monomyth, Joseph Campbell writes, the hero will have a meeting with "the perfect beloved" (Pathways 116), who represents "the bliss-bestowing goal of every hero's ... quest" (J. Campbell, Hero 92); Campbell calls this figure, who is often personified as a woman, the "Goddess," and it is she who, through a "mystical marriage" (100), provides the hero with the strength needed to win in the end. For Adora, this "marriage" occurs in the fourthseason episode "Hero," when, in the remains of Mara's ship (cf. "the darkness of the deepest chamber," 91), Adora is "united" via holographic technology with the previous She-Ra. Mara's holograph explains that both she and Adora have been lied to, and that Light Hope has been grooming Adora to serve as a trigger for a First Ones superweapon known as the Heart of Etheria, which will destroy Etheria and much of the universe if it is detonated. Mara reveals that after learning this truth, she used the Heart's magic to teleport Etheria into a pocket dimension. This kept the planet hidden from the universe, thereby foiling Light Hope's plan, but it also claimed Mara's life. Before the recording ends, Mara has one final message for her successor: "Adora, I believe in you. You can save the world we love" ("Hero"). With these parting words, Mara directly references what Campbell argued was the goddess's gift to the hero: the "boon of love" (99) - and it is this love that Adora will need if she is to win in the end.

Adora now knows that Light Hope is not some benevolent guardian, but a cold, calculating machine that was designed to set off the Heart of Etheria no matter the price. In a desperate attempt to stop the madness, Adora journeys to the Crystal Castle - a location akin to Vogler's articulation of the "inmost cave" (Vogler 143) wherein "the hero is [to be] literally or metaphorically reborn" (Batty 65) - to confront Light Hope. Adora's story and the series as a whole is now at the "Ordeal" (or, its central point), which Campbell's argues usually revolves around the hero atoning with their father or a father-like hero. In She-Ra, however, this sort of paternal confrontation is delayed until the Return stage, and the Ordeal here focuses on Adora confronting her fallen mentor Light Hope.

When Adora stands before the projection of Light Hope, the AI transforms from an otherworldly mentor into an alien temptress, who tries to seduce Adora with the promise of ultimate power vis-à-vis the Heart of Etheria. Adora urges her fallen mentor to stand down, but talking does little good. Light Hope instead commences with her plan: seize control of Adora via the Sword of Protection, force her to activate the Heart of Etheria, return the planet to its original dimension, and use the Heart to destroy the First One's enemies. Light Hope attempts one last time to sway Adora, appealing to her supposed heroic destiny: "This is your intended function. You will bring the First Ones to glory. It is what you were born to do" ("Destiny"). As was 
previously discussed, Adora does have something of a hero complex. Should not she embrace her destiny? Is not that what heroes do?

Not so fast.

Adora now recognizes that for some time now, she has been but a pawn for the First Ones, and being coerced to obey the whims of a master is not what makes one a hero. Instead, heroism is a "journey of continuous re-creation and self-discovery" (Palumbo 3), wherein the hero "recover[s] the unrealized, unutilized potential" in her heart and uses it to make the world a better place (J. Campbell, Pathways 119). And what is in Adora's heart? The answer-which Mara's message had earlier hinted at - is love. Adora is a hero because she truly wants to save the universe she cares for, not destroy it with the holy flames of Etherian magic! And so she declares: "I won't be controlled... I am not a piece of [the First One's] machine... I am not a weapon... And I'm going to end this now" ("Destiny"). Summoning all her strength, Adora then smashes the Sword of Protection against the ground, shattering it into pieces; this powers down the Heart and causes Light Hope to fade away.

This is a shocking moment, given that the Ordeal of the monomyth often features a hero very literally "seizing a sword" (Vogler 178), and by having Adora destroy her sword, the show is directly subverting the audience's monomythic expectations. But unlike other acts of what one might call "symbolic self-castration," Adora's destruction of the sword is paradoxically a move of empowerment, as it frees her from the shackles of the First Ones, clearing the way for her to fully embrace the love at the core of her being. This will prove key in making peace with her Shadow and finally becoming the hero the universe needs.

\section{"We're gonna win in the end!": The Return}

Alas, while Adora may have resisted the Light Hope and discovered the truth about heroic nature, her breaking of the sword also severed her ability to physically turn into She-Ra. This is quite the issue, given that Light Hope's scheming managed to teleport Etheria back into its original dimension, and now Horde Prime-Hordak's lord, emperor of the universe, and a manifestation of the "father-ogre" archetype (J. Campbell, Hero 107, 116) who enforces "the paternal symbolic order" (Creed 21) - has taken notice of the newly-emerged planet. The emergence of Horde Prime immediately after the Ordeal is a unique variation of the monomyth's structure that combines what Vogler calls a "villain escape" with a "setback," wherein "a sudden catastrophic reversal of the hero's good fortune ... seem[s] to doom the adventure" by unleashing a new villain into the world (Vogler 192).

Horde Prime's first act is to beam up Hordak, Glimmer, and Catra into his flagship located deep in space, whereupon he "reconditions" Hordak, purging him of his individuality. The new big bad then turns his attention to Glimmer and Catra, implying that he plans to destroy the "mess" that is Etheria. The emperor's hand is stayed, however, when Glimmer reveals the existence of the Heart of Etheria. Horde Prime is intrigued by its potential power and decides to secure it for his own use. While this is going on, Adora and her friends locate the position of Horde Prime's fleet and take to the stars in Mara's old ship, determined to save Glimmer.

Meanwhile, on Horde Prime's ship, Glimmer and Catra are held as veritable prisoners. With only Glimmer and her guilty consciousness (which has been simmering for several season now) as company, Catra begins questioning her past behavior, which leads her to remember a time in her youth when Adora promised that she would "always be [Catra's] friend" ("Corridors"). Catra suddenly recognizes all the pain she has caused. She thus turns on Horde Prime and, in an attempt to "do one good thing in [her] life" ("Corridors"), helps Glimmer 
escape Horde Prime's ship via a transporter. Before she is overwhelmed by Horde Prime's minions, Catra beams a final message to Adora's ship: "I'm sorry for everything" ("Corridors"). This message, along with Glimmer's safe return, encourages Adora and her friends to set out to save Catra, too.

Adora and her friends bravely pilot Mara's old vessel to Horde Prime's flagship, venturing into the "belly of the beast" (poetically mirroring the "Belly of the Whale" stage discussed earlier). Adora then submits herself before Horde Prime, who reveals that he has implanted Catra with a microchip, digitally lobotomizing her into his mindless crony. Primecontrolled Catra attacks Adora, and in the struggle, Catra's chip is damaged but she is also gravely wounded. All seems lost until Adora, bubbling over with emotion at the thought of losing her former friend, conjures out of air a spirit-sword and uses it to turn into an "Ultimate" form of She-Ra. Adora then steals Catra's crumpled body away onto Mara's ship, and using her mystical powers, heals Catra of her wounds. Soon thereafter, Adora and Catra begin the arduous task of repairing their damaged relationship.

The rescue of Catra combines several monomythic elements into one emotional episode. First, the fact that Adora and her friends have to outsmart and outrun Horde Prime recalls the magic flight, which Campbell argues is taken by the hero when "the trophy has been attained against the opposition of its guardian" (J. Campbell, Hero 170). Second, and more specifically, the fact that the "trophy" is Catra means that the entire episode can be considered a variant of what Campbell called the "bride-theft" (211), in which "the hero has lost [her] beloved and goes to steal her back from the ogre who has taken her" (J. Campbell, Pathways 118). It is important to remember that in this case, Adora's "beloved" is also her Shadow. As such, by saving her former foe, Adora has symbolically recognized that her Shadow "is not necessarily always an opponent" and is instead an aspect that needs to be rehabilitated "by giving love" (von Franz 173). Adora is now close to full enlightenment, represented by her brief — but powerful — ability to tap back into the power of the She-Ra and heal Catra.

As Adora and her friends travel back to Etheria (very literally crossing the return threshold), Horde Prime unleashes a nasty computer virus that begins hacking into the Heart. With the clock ticking, Adora and her allies learn of a secret failsafe which will power down the Heart, but the one who activates said failsafe will almost certainly die. Adora volunteers to be the sacrifice, but when she journeys to the Heart, she is overcome by Horde Prime's virus. Adora keels over, only to be caught by Catra, who has refused to leave her side, even if it means sure death. As Adora slips away, Catra cradles her friend's failing body, declaring: "Don't you get it? I love you! I always have! So please... just this once... stay" ("Heart"). This is Adora's rescue from without; this is the moment in the story when the hero is on the brink of defeat, necessitating that her unconscious - personified as Catra- "supplies its own balances," bringing the hero "back into the world from which [she] came" (J. Campbell, Hero 186).

Catra's declaration snatches Adora from the maw of death and releases her latent She-Ra power, which manifests as a shield that protects them from the Heart's unstable power. Adora confesses that she too loves Catra, and then the two kiss - an act so powerful that it fully unlocks the Heart's failsafe. This kiss between Adora and Catra is arguably the most important moment in the show, as it symbolizes coniunctio of the Shadow and consciousness. For Adora, this union provides her with the Ultimate Boon: the recognition of true love, and more specifically, the recognition that she can still be Etheria's hero without having to suppress her romantic attraction to Catra. As both fully She-Ra and fully herself, Adora is now the master of the two worlds. 
Channeling this now-conscious love, Adora turns into the "Ultimate" form of She-Ra once again and journeys to the surface of Etheria in all her glory. This is Adora's moment of full enlightenment - her apotheosis. Our hero then uses her powers to turn Horde Prime's ship into a giant floating tree before unleashing a magical burst that "heal[s] [the] wounded land" (Vogler 215) with a wave of vegetation. Adora next turns her attention to the big bad himself, who is currently possessing the body of the "reprogrammed" Hordak. Adora tells her foe, "It's time for you to go" before she exorcises the dreadful ogre into the oblivion of the light (cf. J. Campbell, Hero 110), symbolically purging the world of hateful, patriarchal oppression. Hordak, freed from the mental snares of his overlord, then remembers the time he found Adora as a baby, telling the hero: "I remember you" ("Heart"). In this instance, Adora very literally "beholds the face of the [adoptive] father [and] understands" that he was but a puppet of a larger, more insidious villain (J. Campbell, Hero 125). The two are thus atoned.

The final stage of the monomyth is what Campbell calls the "freedom to live." It is at this point in the story that the hero learns to simply live in the moment, neither stressing about the unchangeable past nor the unknown future. For Adora, this freedom manifests in the dissolution of her heroic martyr complex, meaning that Adora can now live for herself as well as for others. With her friends and lover by her side, Adora is now determined to share her boon and "bring magic back to the universe" ("Heart").

\section{Queering Monomythic Heroism}

She-Ra and the Princess of Power is far from the first piece of media to use the monomyth as its foundation. That said, the show is notable for taking Campbell's normative structure and reworking — and in some instances, subverting - it so as to productively queer it. The show does this in two major ways: by problematizing heteronormative understanding of heroic gender, and by pushing back against Campbell's inherent heterosexism.

\section{Queering Heroic Gender}

Perhaps the most visible issue with regard to Joseph Campbell is that of gender. As many have pointed out, The Hero with a Thousand Faces focuses, with only a few exceptions, almost entirely on male heroes (Byfield 30; C. Campbell 3-6; Creed 18; Frankel, Girl to Goddess 3; Morgan 59-60; Murdock 1; Nicholson 187-188), and even when Campbell does discuss the heroas-a-woman, it is usually in relation to marriage or the "heroic act" of childbirth (Byfield 30; Campbell and Moyers 125). Additionally, Campbell's language is thoroughly patriarchal (Morgan 59), which reifies the idea that the "default" hero is a male. For many, this "static theory of gendered heroism" (C. Campbell 4) is problematic for being androcentric, binarist, and sexist, given that it: places men at the center of the story; assumes that there are only two genders worth discussing; and emphasizes "traditional," heteronormative gender roles. The critics thus argue that when Campbell's articulation of the monomyth is reproduced by a writer taught only to "stick to the hero's journey," the result is usually a story featuring a male action hero who saves a stereotypical "damsel-in-distress."

In an attempt to subvert this "damsel-in-distress" trope as well as the androcentricism of the monomyth, some writers have developed "strong" female protagonists. They are active, assertive, stoic, resilient, unemotional, and bold; and they definitely do not need a man to save them. Alas, this tactic is less than ideal, for inversions are not necessarily subversions (Salih 6667). Indeed, the end product of this "girl power" approach is what some call "phallic women"that is, characters who while superficially coded as female repudiate normative understandings 
of femininity by possessing attributes associated with normative masculinity (e.g., physical strength, proficiency with weapons, a lack of emotions) (McRobbie; see also Morgan, 59-60; Sadri 2). As Angela McRobbie writes, these phallic women attempt "to emulate male behaviour as a post-feminist gesture ... which ... confirms and consolidates patriarchal privilege and masculine hegemony by apportioning some limited features of this privilege to young women" (McRobbie 733). This means that these characters can, in the eyes of some, reify hegemonic masculinity vis-à-vis the embrace of its key attributes. This in turn can lead to the implication that heroism is the domain only of "men or those who act like them" (Frankel, Girl to Goddess 3 ), which is decidedly sexist, despite being covered by a veneer of "equality."

Another method used to subvert the apparent sexism of the monomyth is to lean the other way and embrace enthusiastically what it means for a hero "to be a woman." This approach has been conspicuously embraced by scholars like Maureen Murdock, Valerie Estelle Frankel, and Victoria Lynn Schmidt, who have articulated a complementary "heroine's journey" that details the overlooked exploits of women heroes. This approach does not denigrate attributes traditionally associated with femininity, which is a major step in the right direction, but it still has its issues. As Catherine Bailey Kyle noted, theorists who write about the heroine's journey "are all coming at this conversation from the perspective of depth psychology [which] ... tends to argue in favor of distinct differences between males and females" (Kyle 134). In other words, by positing a female heroine's journey in opposition to the hero's journey, theorists like Murdock, Frankel, and Schmidt are still lapsing into a binarism that sees the question of heroism as being one between "male" and "female," "hero" and "heroine."

The solution for overcoming the androcentricsim, sexism, and binarism upon which the monomyth is seemingly predicated, however, is fairly simple: Writers need to develop monomythic heroes who are "active, diverse, and complex" (Smith and Cook 12), and who cannot be readily defined solely on the basis of gender or pre-existing gender roles.

Adora's characterization in She-Ra is epitomic of this approach. As the strong, swordwielding champion of Etheria, the character may to be just another phallic woman, but this understanding is problematized when one takes a closer look. While it is true that Adoraespecially in her She-Ra persona-engages in what many cultures would call "masculine" behaviors (e.g., fighting), it must be remembered that she is also more than willing to eschew these behaviors when she realizes that they might be counterproductive. The best example of this is her destruction of the Sword of Protection in the episode "Destiny"; in many cultures, the sword is a culturally-coded phallic symbol of what one might traditionally call "masculine" traits, such as violence, aggression, and physical strength, to name but a few. By destroying the sword rather than seizing it aggressively, Adora very literally strips heroism of its phallogocentric baggage, illustrating that heroes are more than just men swinging swords.

Likewise, Adora's heroism is never called into question when she asserts her identity as a woman, or when she embraces behaviors or attributes that are traditionally coded as "feminine" (such as when she heals Catra in season five's "Save the Cat," or when she passionately cries at the end of season one's "Promise"). And sometimes Adora even embraces "masculine" and "feminine" traits at the same time, like when she uses the power of love and blunt force to beat back the Horde in the first-season finale "The Battle of Bright Moon."

By continually emphasizing that Adora is a hero while also ascribing to her a complex lamination of behaviors associated with both heteronormative "masculinity" and heteronormative "femininity," the show makes its message clear: Neither the "masculine" nor "feminine" approach is "good" while the other is "bad". Instead, it is always a matter of context 
and need. If punching is necessary to save the day, so be it, but if nurturing is more appropriate in the moment, so too it should be.

It is worth mentioning that this sort of gendered nuance is by no means confined to just the heroes. For instance, Catra is, out of all the characters, perhaps the show's most emotional (a trait associated with heteronormative "femininity"; Prentice and Carranza 273-274, 277), but she is also an aggressive and skilled warrior (a trait long associated with heteronormative "masculinity"; Prentice and Carranza 269, 273-274, 277). Likewise, Scorpia is a hulking halfcrab, half-human with powerful muscles (a "masculine" trait; Prentice and Carranza 269, 273 274, 277), but personality-wise, she is loving and extremely warmhearted ("feminine" traits; Prentice and Carranza 269, 273-274, 277). And finally, there is Double Trouble, the non-binary changling who throughout the fourth and fifth seasons functions in a bevy of archetypical roles (including as a shapeshifter, an ally, a trickster, and a shadow; see Vogler 59-80) —all the while appearing in a variety of (non)genders. The end result is a clear illustration that the characters appearing in the monomyth - heroes and villains alike - need not be tethered to any one specific gender for them to carry dramaturgical weight.

\section{Queering Heroic Sexuality}

The second issue with Campbell's monomyth is that it approaches the question of heroism almost exclusively from a heterosexist worldview. According to the researchers Kathleen Farrell, Nisha Gupta, and Mary Queen, "Heterosexism refers to the dominant cultural belief that heterosexuality is the one 'normal' and 'right' sexuality for all people" (Farrell et al. 186). This belief is expressed implicitly throughout Campbell's writings, but is perhaps most obvious when he discusses the hero's interaction with a goddess figure (J. Campbell, Hero 91), and to a greater extent when he explores the hero as a lover (J. Campbell, Hero 293-295). It is therefore no accident that $S h e-R a$ further queers the monomyth by playing with heterosexist expectations.

When discussing the meeting with the goddess, Campbell argues that a male hero will meet "the Queen Goddess of the World" (J. Campbell, Hero 91) while a female hero-in the rare instance she is the focus of the story-is destined to instead "become the consort of ... [a] heavenly husband," who "descends to her and conducts her to his bed-whether she will or no" (J. Campbell, Hero 99). Suffice it to say, She-Ra subverts this expected plot point in a decidedly queer way, as there is no "heavenly husband" who swoops down and woes Adora or sweeps her off her feet. Instead, Adora meets with a bona fide goddess figure, Mara. During this meeting, Mara imparts unto Adora the strength needed to save the world, suggesting that love is the key (cf. the "boon of love" as discussed in J. Campbell, Hero 148-166). By having an explicitly female hero meet with a goddess figure, the show thus rejects Campbell's heterosexist assumption that the only possible pairings are male hero/feminine deity and female hero/masculine deity. She-Ra instead illustrates that as long as a "heavenly figure" provides aid to the hero in some way, the characters need not conform to the heterosexual binary.

When it comes to discussing the hero as a lover, Campbell argues that many iterations of the monomyth feature the hero saving a woman, who represents "the life energy released from the toils of the tyrant Holdfast ... She is the maiden of the innumerable dragon slayings, the bride abducted from the jealous father, the virgin rescued from the unholy lover. She is the 'other portion' of the hero himself - for 'each is both"' (J. Campbell, Hero 293). Needless to say, this passage is rife with heterosexist wording that presumes a male/female union, and further compounding the issue is that fact that every mythological anecdote Campbell discusses in this 
section focuses on a male hero winning over a bride (J. Campbell, Hero 293-295). She-Ra once again rebukes this heterosexism directly, showcasing a female hero (something that Campbell does not even mention when discussing the hero as a lover; Creed 19), who woos another woman, Catra. What is more, because Catra functions as Adora's Shadow, it can very literally be said that "she is the 'other portion' of the hero" (J. Campbell, Hero 293) who allows Adora to embrace her queer desires and live for herself (cf. "life energy released from the toils of the tyrant") (J. Campbell, Hero 293). By subverting this heterosexism, She-Ra clearly queers what heroic sexuality "means."

And once again, this subversion of heterosexism is not confined to just the hero. Instead, She-Ra foregrounds queer sexuality by featuring a number of supporting characters (such as the princesses Spinnerella and Netossa, as well as Bow's fathers, George and Lance) who are in visibly queer relationships. And while $S h e-R a$ breaks down much of the heterosexism that permeates the original articulation of the monomyth, the show is by no means "heterophobic" (if such a thing can be said to exist). Instead, true equality of sexualities is emphasized, with the aforementioned queer pairings visibly featured alongside pairings that can readily be considered heterosexual, such as Bow and Glimmer, Queen Angella and King Micah, Mermista and Seahawk, and Princess Entrapta and Hordak. When it comes to sexuality, She-Ra is thus fundamentally queernormative (cf. Fielding) in that it portrays queer relationships as equal to, rather than opposed to or better than, heterosexual relationships. ${ }^{2}$

\section{Broader Implications}

In this paper, I have sought not to further the line of thought - commonly heard in modern departments of comparative mythology as well as within some writing circles - that Joseph Campbell and his monomyth should be tossed into the dust bin of scholarly history; instead, I have attempted to do quite the opposite, using She-Ra as proof positive that while Campbell's articulation of the monomyth was indeed limited by his own androcentrism, binarism, and heterosexism, the core of the monomyth can nevertheless be adapted in queer, non-normative ways. By illustrating that the monomythic hero-contrary to popular understandings - need neither be a man nor conform to the expectations of a heterosexist worldview, She-Ra and the Princesses of Power is thus the proverbial skeleton key that can further unlock the potential of the monomyth and "rehabilitate" its storytelling potential in our modern world.

This means that individuals who want to write a compelling queer story replete with queer characters and queer themes need not reinvent the entirety of the wheel. They can instead reach for their well-worn copy of Hero with a Thousand Faces, strip away the problematic elements, and let the core of the monomyth guide them from there.

\footnotetext{
2 The exact nature and impact of She-Ra's queernormativity is a topic worthy of further analysis, but it is beyond the scope of this present paper.
} 


\section{Bibliography}

Batty, Craig. Movies That Move Us: Screenwriting and the Power of the Protagonist's Journey. Palgrave Macmillan, 2011.

Byfield, Bruce. "The Secret Queen: Two Views of the Heroine in Diana Paxson's the White Raven." Mythlore, vol. 18, no. 67, 1991, pp. 30-48.

Campbell, Caitlin. Heroes and Heroines: A Feminist Analysis of Female Child Protagonists in the Epic Fantasies of George Macdonald, C.S. Lewis, and Philip Pullman. Master's degree thesis, University of British Columbia, 2009.

Campbell, Joseph. The Hero with a Thousand Faces. Third edition, New World Library, 2008. . Pathways to Bliss: Mythology and Personal Transformation. New World Library, 2004.

Campbell, Joseph with Bill Moyers. The Power of Myth. Edited by Betty Sue Flowers, Paperback edition, Anchor Books, 1991.

Casement, Ann. "The Shadow." The Handbook of Jungian Psychology, edited by Renos K. Papadopoulos, Routledge, 2006, pp. 94-112.

"Corridors." She-Ra and the Princesses of Power, season 5, episode 3, DreamWorks, 2020.

Creed, Barbara. "The Neomyth in Film: The Woman Warrior from Joan of Arc to Ellen Ripley." Women Willing to Fight, edited by Silke Andris and Ursula Frederick, Cambridge Scholars Publisher, 2007, pp. 15-38.

"Destiny." She-Ra and the Princesses of Power, season 4, episodes 12-13, DreamWorks, 2019.

Farrell, Kathleen et al., editors. Interrupting Heteronormativity: Lesbian, Gay, Bisexual, and Transgender Pedagogy and Responsible Teaching at Syracuse University. The Graduate School of Syracuse University, 2004.

Fielding, Dan Michael. "Queernormativity: Norms, Values, and Practices in Social Justice Fandom.” Sexualities, 2020, doi:10.1177/1363460719884021.

Frankel, Valerie Estelle. From Girl to Goddess: The Heroine's Journey through Myth and Legend. McFarland \& Company, 2014.

- Turning Darkness to Light: She-Ra: The Classic, the Reboot, and the Heroine's Journey. LitCrit Press, 2019.

"Heart." She-Ra and the Princesses of Power, season 5, episodes 12-13, DreamWorks, 2020. "Hero." She-Ra and the Princesses of Power, season 4, episode 9, DreamWorks, 2019. Jung, Carl. The Quotable Jung. Edited by Judith Rachel Harris, Princeton University Press, 2015.

Kyle, Catherine Bailey. "Her Story, Too: Final Fantasy X, Revolutionary Girl Utena, and the Feminist Hero's Journey." Heroines of Film and Television, edited by Norma Jones et al., Rowman \& Littlefield Publishers, 2014, pp. 131-46.

McRobbie, Angela. "Top Girls? Young Women and the Post-Feminist Sexual Contract." Cultural Studies, vol. 21, no. 4-5, 2007, pp. 718-37.

Morgan, Robin. The Demon Lover: The Roots of Terrorism. 2nd edition, Washington Square Press, 2001.

Murdock, Maureen. The Heroine's Journey: Woman's Quest for Wholeness. Shambhala Publications, 1990.

Nicholson, Sarah. "The Problem of Woman as Hero in the Work of Joseph Campbell." Feminist Theology, vol. 19, no. 2, 2010, pp. 182-93.

Palumbo, Donald E. The Monomyth in American Science Fiction Films: 28 Visions of the Hero's Journey. McFarland and Company, 2014. 
Prentice, Deborah and Erica Carranza. "What Women and Men Should Be, Shouldn't Be, Are Allowed to Be, and Don't Have to Be: The Contents of Prescriptive Gender Stereotypes." Psychology of Women Quarterly, vol. 26, 2002, pp. 269-81.

"Promise." She-Ra and the Princesses of Power, season 1, episode 11, DreamWorks, 2018. "Razz." She-Ra and the Princesses of Power, season 1, episode 3, DreamWorks, 2018.

Sadri, Houman. "The Super-Heroine's Journey: Comics, Gender and the Monomyth." 3rd Global Conference Of The Graphic Novel, 2014, pp. 1-8.

Salih, Sara. Judith Butler. Routledge, 2002.

She-Ra and the Princesses of Power. Created and produced by Noelle Stevenson. DreamWorks, 2018-20.

Smith, Stacy and Crystal Cook. "Gender Stereotypes: An Analysis of Popular Films and TV." The Geena Davis Institute on Gender and Media, 2008.

"The Sword." She-Ra and the Princesses of Power, season 1, episodes 1-2, DreamWorks, 2018. Vogler, Christopher. The Writer's Journey: Mythic Structure for Writers. 3rd edition, Michael Wiese Production, 2007.

von Franz, Marie-Louise. “The Process of Individuation.” Man and His Symbols, edited by Carl Jung and Marie-Louise von Franz, Revised edition, Anchor Press, 1988, pp. 158-229. 